\title{
WTO Dispute Settlement in 2015: Going Strong after Two Decades
}

\author{
CHAD P. BOWN * \\ Peterson Institute for International Economics \& CEPR \\ PETROS C. MAVROIDIS * * \\ Columbia Law School
}

\section{Twenty years on}

On 1 January 1995, the WTO and its new and sophisticated dispute settlement system entered into force. We have thus already entered the twenty-first year of its life. Although the number of disputes has dropped somewhat over the last decade, there is no sign of weakening. Indeed, during 2015, the year we discuss in this volume, the WTO adjudicating bodies issued 16 reports, including three reports discussing the extent of the reasonable period of time.

As is customary, this annual project sets out to examine only the final reports, that is, all Appellate Body (AB) reports issued, as well as the panel reports against which no appeal is possible. In total, we present here ten reports.

\section{Another diverse year}

The ten reports discussed in this volume are thematically quite heterogeneous.

Five of them concern mainly Annex 1 Agreements, that is, Agreements in the realm of trade in goods that are customarily treated in case law as lex specialis to the GATT. Four of them deal with contingent protection instruments, whereas one report discusses one of the thorniest issues in WTO law, the measurement of retaliation. Eight of them concern challenges against original measures, whereas on two occasions the WTO adjudicating bodies faced complaints against compliance measures. Finally, six of the papers presented here are comments on reports by the $\mathrm{AB}$, whereas the remaining four discuss Panel Reports.

During our annual meeting, which was held at the European University Institute in Florence, Italy on 16-17 June, we introduced an innovation. We invited a paper on the case law regarding Article 21.3c of the Dispute Settlement Understanding (DSU). According to this provision, when parties cannot reach a bargaining solution regarding the reasonable period of time during which compliance should

*Email: cbown@piie.com

**Email: pmavro@law.columbia.edu 
occur, they can ask an Arbitrator to pronounce on this score. We were prompted by the fact that three such reports were issued in 2015, as well as by our past decision not to invite papers regarding the calculation of the reasonable period of time. We have now filled this gap.

\section{The research}

In what follows, we group papers under common themes. Hence, we first present the papers dealing with contingent protection instruments, then those dealing with Annex 1A Agreements, then the paper on calculation of retaliation, and finally the contribution regarding the case law under Article 21.3c.

Ahn and Zanardi explain how, to some degree, the AB report on China-HPSSST (Japan) follows earlier ones involving China, as similar procedural and substantial issues had already been raised in previous cases. They do note that this is the first time that the WTO Panel had rejected some important claims regarding both substantive (e.g., injury) as well as procedural issues (confidentiality) only for those decisions to be reversed by the AB. Now that various rulings have clarified these legal issues, it remains to be seen if China-HP-SSST (Japan) represents the last stage of growing pains for Chinese authorities to learn about such basic antidumping legal procedures.

Through the lens of the AB report in US-Shrimp II (Vietnam), Wouters and Zissimos explore the idea that the US Department of Commerce (USDOC) imposed anti-dumping duties on Vietnamese shrimp producers despite the fact that the surge of shrimp imports giving rise to the duties may have come from elsewhere in the developing world. The authors argue that Vietnam may have been targeted for anti-dumping duties because it has 'non-market economy' (NME) status, making it easier to levy higher duties against Vietnamese firms. They make the point that it was particularly inappropriate to impose antidumping duties against the Vietnamese shrimp industry because this industry shows clear indications of being perfectly competitive, whereby firms cannot profitably dump. This in turn raises, in their view, the question of how the USDOC was able to construct a dumping case where apparently none could have existed. Use of zeroing methodology, in conjunction with Vietnam's NME status, turns out to be central to the answer. The broader issue is that antidumping duties are overused where safeguards would be more efficient. Their analysis is relevant for the current controversy over China's NME status with a number of its trade partners.

The China-GOES (Article 21.5) (US) dispute concerns the measures China took to implement the Dispute Settlement Body's rulings in China-GOES, the original dispute between the two parties, which had found a number of violations with respect to China's antidumping and countervailing duties imposed on grain oriented flat-rolled electrical steel (GOES) imported from the United States. In this compliance proceeding, the United States claimed that the Redetermination issued by China's Ministry of Commerce (MOFCOM) continued to violate 
WTO law. Qin and Vandenbussche examine issues at the center of the dispute, including MOFCOM's findings that the US imports had the effect of suppressing and/or depressing the prices of domestic like products. While the Panel had reached the conclusion that the MOFCOM findings were inconsistent with WTO rules, it did not clarify the criteria for determining such price effects. In their comment, the authors call for the adoption of a clearer and more objective standard for determining price suppression/depression in antidumping and countervailing duty investigations, via the tools of economic modeling.

The Panel Report in Ukraine-Passenger Cars provides, in the view of Gnutzmann-Mkrtchyan and Lester, an opportunity to revisit an old debate over the role of safeguard measures in the WTO. With regard to the legal findings, the panel followed the established jurisprudence in this area and found a number of violations of the Safeguards Agreement. With regard to the economics, the authors delve more deeply into the economic and political background of the safeguards investigation. Ukraine was hit by the economic crisis shortly after its WTO accession that had led to significant liberalization of its import tariffs on passenger cars. Based on this observation, the authors offer a de novo look at the injury and causation issues in this case, and discuss the challenges of an industry reliant on offshored production that sees a safeguard as a mechanism to attract FDI for production. They conclude with an assessment of the operation of the WTO's safeguards regime, along with some tentative suggestions for reform. Overall, their examination of the economic analysis by the investigating authority and the legal review by the WTO panel raises questions about particular aspects of the domestic and WTO processes. They still take the view that the system has worked well in this case.

Bown and Hillman examine the Panel Report in US-Animals, another WTO dispute arising due to challenging conditions under which an importing country fails to adequately re-open its market after an infectious-disease outbreak in a trading partner. The US had banned imports of beef from Argentina following a 2000 Argentine outbreak of highly contagious foot-and-mouth disease (FMD). The US, the requests to this effect notwithstanding, refused to relax its import ban, and Argentina filed a WTO dispute in 2012, more than six years after its last FMD outbreak. One issue is Argentina's claim that the gap between its first requests - in 2002 - to restore its trading rights and no action by the US as of 2012 constituted undue delay. The authors address this and other issues by drawing on classic economic insights from asymmetric information problems of moral hazard and adverse selection to describe the difficulties ultimately confronting the World Organization for Animal Health (OIE) and the WTO's SPS Agreement in dealing with FMD. Such an environment creates disincentives for socially efficient behavior that were clearly realized in this particular episode. The exporting country has an incentive to hide information on outbreaks and report being disease-free too quickly, and the importing country has no incentive to quickly undertake the costly effort of conducting the necessary inspections to 
restore the exporter's market access. Adjudicators will eventually be called to distinguish wheat from chaff.

The AB report of India-Agricultural Products provides Saggi and Wu another opportunity to examine the issue of imported agricultural products deriving from a trading partner experiencing an animal disease outbreak - in this instance, avian influenza. The authors explain why, despite the negative externalities associated with diseased imports, an importing country is generally not permitted to ban such imports outright under WTO law. Rather, it is allowed to do so only under fairly specific circumstances. They also highlight how the ruling in this report contributes to the jurisprudence of two issues concerning the SPS Agreement: the interpretation of international standards, and the relationship between the risk assessment and scientific evidence requirements.

Shaffer and Winters assess the AB report in Peru-Agricultural Products and note that prima facie, and probably mundanely so in light of existing case law, the case addressed the consistency with WTO rules of Peru's Price Range System (PRS) (Sistema de Franja de Precios). The case involved the PRS for four categories of agricultural products (milk, maize, rice, and sugar), pursuant to which Peru's tariffs could vary fortnightly as a function of historical world prices. More systemically, since Peru and Guatemala had agreed in a bilateral free trade agreement (FTA) that 'Peru may maintain its Price Range System', the AB decision had to address the interaction of WTO law with FTA rules and public international law generally. They identify the case as being important for trade policymakers and scholars addressing a world of fragmented international treaties and institutions.

In the compliance decision of US-Tuna II (Mexico) (Article 21.5-Mexico), Coglianese and Sapir find that the $\mathrm{AB}$ reaffirmed its view that regulatory distinctions embedded in the US dolphin-safe tuna labeling regime were not legitimate because they were not sufficiently calibrated to the risks to dolphins associated with different tuna fishing conditions. The authors examine the AB's application of the notion of risk-based regulation in the US-Tuna II dispute and finds the AB's reasoning lacking in coherence. In their view, although risk analysis and calibration can in principle play useful roles in TBT cases, the AB needs to provide more explicit and careful guidance to WTO members and to panels to avoid the kind of ad hoc decision-making exhibited throughout the US-Tuna II dispute.

Conconi and Schepel examine the AB report in Argentina-Import Measures, a dispute concerned with a series of measures imposed by Argentine authorities on economic operators as a condition for obtaining import licenses. These measures were introduced with the goal of advancing the Argentine government's stated policies of re-industrialization, import substitution, and elimination of trade balance deficits. The authors note that, from a legal point of view, the least interesting feature of the dispute was the substantive compatibility of these measures with Article XI:1 GATT as they clearly constituted import restrictions. Identifying and classifying the measures involved, however, proved more challenging: based on vague policy guidelines, devoid of any legal basis, and consisting largely of 
wholly discretionary ad hoc action by the authorities, clouded in confidential obscurity, the measures escaped familiar categories and distinctions of WTO law. In their analysis of the case, the authors further show that, from an economic perspective, although Argentina's measures appear to have had no impact on its overall imports, they imposed large costs on foreign companies, as well as on Argentine importers and consumers.

The contribution by Bown and Brewster examines the Article 22.6 arbitration report of the WTO dispute over the United States' country of original labeling (US-COOL) regulation for meat products. At prior phases of the legal process, a WTO Panel and the Appellate Body had sided with Canada and Mexico by finding that the US regulation had negatively affected their exports of livestock to the United States. While only the twelfth WTO dispute to reach the stage of an arbitration report, the arbitrators here authorized Canada and Mexico to retaliate by over $\$ 1$ billion against US exports, the second largest authorized retaliation on record. The authors utilize a simple, economics-based model to explain the arbitrators' rejection of a complainant proposal to consider a new formula for computing the permissible retaliation limit that would also include the effects of domestic price suppression. Second, while the arbitrators relied on the 'trade effects' formula - which sets the retaliation limit as equivalent to the perceived loss of export revenue resulting from the WTO violation - an analysis of the US market context suggests this amount to be implausibly large, given the actual US market conditions for cattle and hogs during this period.

Finally, Mavroidis, Meagher, Prusa, and Yanguas examine the case law under DSU Article 21.3c which allows a defending Member a 'reasonable period of time' (RPT) to implement any findings that its contested measures are inconsistent with WTO law. If agreement on this RPT cannot be reached, Article 21.3c provides for the possibility of arbitration on the length of the RPT. The DSU provides limited guidelines on the RPT, stating only that it should not normally exceed 15 months. The authors show that, in practice, Arbitrators have developed the standard that the RPT should reflect the shortest possible period under the domestic legal system of the defending Member to make the changes necessary to comply with the WTO rulings. Their research confirms that in practice Arbitrators have determined this period by 'splitting the difference'approximately between the periods suggested by the complaining and defending Member. In addition, the process appears to reward defending Members that request an RPT that exceeds the 15month guideline in Article 21.3(c).

\section{Concluding remarks}

As of the time of writing, the $\mathrm{AB}$ is in the process of appointing two new members, while panel reports are being issued on some of the most controversial issues, like 'green' subsidies. Our next year's event already promises to be exciting. 
The case law of 2015 has confirmed prior case law in part (especially in the realm of contingent protection), did not manage to persuasively address some issues (such as nondiscrimination in the context of the TBT Agreement, or the manner in which equivalence is calculated in the realm of authorized retaliation), and has left some open questions (the relationship between FTAs and the WTO). As ever, it was a year that attracted a lot of interest in academic writing, including the efforts that you will find in the pages of this volume. 